\title{
Palm Oil Mill Effluent Treatment Process Evaluation and Fate of Priority Components in an Open and Closed Digestion System
}

\author{
ANWAR AHMAD* and MOHD. Z. KRIMLY \\ Department of Civil Engineering, College of Engineering, \\ King Saud University (KSU), PO Box 800, Riyadh 11421, Kingdom of Saudi Arabia. \\ http://dx.doi.org/10.12944/CWE.9.2.12
}

(Received: April 15, 2014; Accepted: May 09, 2014)

\begin{abstract}
The evaluation for the degradability of chemical oxygen demand (COD) and biogas contents before and after closed tank reactor (CR) and open tank reactor (TP) were observed. COD reduction in the TP (maximum degradability rate of $60 \%$ ) and $\mathrm{CR}$ (maximum degradability rate of $85 \%$ ). The variation in $\mathrm{CH}_{4}$, volatile fatty acid (VFA) and total suspended (TSS) contents in the effluent was more pronounced in the first six months and found stable afterward. The maximum organic loading rate (OLR) of $11.5 \mathrm{~g}$-COD l/d attained corresponded to $85 \%$ overall COD removal. However, there is study to degradability of $\mathrm{COD}$ and quantify the actual $\mathrm{CH}_{4}$ recover from the commercial scale wastewater treatment from TP and CR. The findings indicated that the $\mathrm{CH}_{4}$ content was between $49 \%$ TP which was lower than the value of $57 \%$ reported in TP. The lower VFAs were found in the $\mathrm{CR}$ because of variation of palm oil mill effluent quality and quantity from palm oil mill industry.
\end{abstract}

Key words: Palm oil mill effluent, Aerobic and anaerobic treatment, COD, biogas, Methane.

\section{INTRODUCTION}

Palm oil mill effluent (POME) is a viscous brown liquid with fine suspended solids at $\mathrm{pH}$ between 4 and $5^{1}$ and a highly polluting wastewater that directly and indirectly contaminates the environment ${ }^{2}$. The chemical properties of POME vary widely throughout the year because of mill operations and seasonal cropping ${ }^{3}$. Atmospheric methane concentrations incredibly increased by $30 \%$ in the last 25 years $^{4}$. Net carbon emission from POME is approximately $1.4 \times 10^{6}$ tons per year ${ }^{5}$. Assuming a mean annual increase of $29 \%$ as experienced from 1990 to $2004^{6}$, the estimated $\mathrm{CH}_{4}$ gas emission may be $0.502 \times 10^{6}$ tons in the year 2020. Certified emission reduction (CER) can be obtained by using methane gas as a renewable energy?.

At high organic loadings or at natural environment temperatures, the insoluble organic degradation of the effluent tends to accumulate within the granules or sludge density region of the ponds, leading to granule destabilization or inhibition of granule formation 8 . To date, $85 \%$ of POME treatment in Malaysia is based on an anaerobic and facultative ponding system, which is followed by another system consisting of an open-tank digester coupled with extended aeration. For every ton of treated POME, an average of $5.5 \mathrm{~kg}$ of $\mathrm{CH}_{4}$ (or approximately $36 \%$ of biogas) is emitted from open digesting tanks ${ }^{3}$. Anaerobic digestion is the most suitable method for the treatment of effluents containing high concentration of organic carbon and thus producing biogas 9 . A typical biogas would comprise $60-70 \%$ methane, $30-40 \%$ carbon dioxide, $0-0.1 \%$ hydrogen sulphide, and $0-10 \%$ hydrogen $^{10}$. Recently, both conventional single-phase and highrate two-phase anaerobic digestion systems have been widely used, for the production of biogasmethane from various substrates, such as the organic fraction of the municipal solid waste, POME, 
food waste, waste-activated sludge, and sugar beet silage $^{11,12}$.

Periodic research has been performed to find amicable solutions for POME management ${ }^{13-}$ 15. The presence and activity of microorganisms in POME treatment are vital to the process. With regard to microbial degradation of POME effluent, biodegradation phenomenon is crucial. Therefore, the steady-state models are basically able to predict the parameters that have been considered in mass balance relations but are unable to estimate the other interrelated effluent quality parameters ${ }^{16}$.

Biodegradation is a metabolismindependent consumption of organic to living cells, nonliving biomass, or microbial extracellular polymers ${ }^{17,18}$. Specific metabolic pathways resulting in bio-precipitation of organic molecules or their mechanisms of degradation have been provided elsewhere ${ }^{19,20}$. Moreover, surface exposure of organic-binding microbes improves organic-binding properties of microorganisms based on degradation and microbial metabolic activities ${ }^{21}$. Binding of organic molecules with microbes is known to reduce the COD and selected biogas $\left(\mathrm{CH}_{4}, \mathrm{CO}_{2}\right.$, and VFAs) ${ }^{22}$ Yacob et al., 2006a S. Yacob, M.A. Hassan, Y. Shirai, M. Wakisaka and S. Subash, Baseline study of methane emission from anaerobic ponds of palm oil mill effluent treatment, Science of the Total Environment 366 (2006), pp. 187-196. Article I PDF (357 K) I View Record in Scopus I Cited By in Scopus (13). Consequently, the removal of COD and treatment of POME effluent with anaerobic and aerobic system also are affected, although many studies have shown that COD can be removed in POME treatment processes ${ }^{23}$.

During POME treatment, a large amount of sludge is produced (approximately $35 \%$ of the treated wastewater). The Malaysian government proposed and legalized standards for POME discharge into watercourses ${ }^{24}$. The results of a oneyear evaluation on the POME degradation was using aerobic, anaerobic digestion of VFA, and removal of COD in terms of selected biogas $\left(\mathrm{CH}_{4}, \mathrm{H}_{2}\right.$, and $\mathrm{CO}_{2}$ ) by an OT and $\mathrm{CR}$ treatment system. The aim of the study were to compare COD, VFA, and biogas contents in the influent and effluent wastewater and to examine the COD and biogas contents in the effluent before and after digestion and compare the performance of our designed treatment system with LSHC POME treatment plant (LSHC-WTP).

\section{MATERIALS AND METHODS}

\section{Description of the Gambang POME treatment plant}

The main objective is to reduce the level of organic pollution and COD removal from POME before discharging it to the environment. Treatment processes were used are shown in Fig. 1

\section{Sample collection}

The raw POME samples were collected every month five sample from LHSC-Palm Oil Mill, situated in the state Pahang, Malaysia. The features and composition of the POME used are summarized in Table 1, which shows the average values of five replicate analyses for each parameter. In comparing the biogas contents in influent and effluent samples (collected from locations 1, 4, 5, and 6), their removal from the influent wastewater was assessed. Because accurate matching of influent and effluent samples was difficult because of large volumes of wastewater or treated sludge, 10 influent and effluent sample pairs were taken to obtain a composite grab sample. Five samples were collected once a month for one year. During each sampling day, three composite grab samples were collected from the influent stream using an automatic wastewater sampler, whereas sample collection from the effluent was done manually approximately $21 \mathrm{~h}$ later; this is an approximate time required for the influent stream to pass through all the wastewater treatment operation units between locations 1, 4, 5, and 6 was mentioned in Fig. 1. Grab samples of mixed sludge (location 4) and digested sludge (location 5) also were collected manually. Digested sludge biogas samples were collected 28 days (retention time of sludge in the anaerobic digester) after collecting the mixed sludge sample, which was the influent, into the TP and CR anaerobic digesters. During the period when these investigations were being conducted, the anaerobic digesters (TP and CR) were yet in operation (Fig. 1). To avoid deterioration or contamination of samples, sampling procedures and sample preservation were done according to the Standard Methods for the Examination of Water and Wastewater ${ }^{25}$. Characteristics of raw and pre-treated POME are 
provided in Table 1 and 2, respectively.

\section{Analytical analysis}

All the tests for the samples were analyzed according to the guidelines of the American Public Health Association ${ }^{26}$ for the examination of water and wastewater. Biogas yield was measured with a wet gas meter (W-NK-O.SA, Shinagawa). Gas samples were obtained through an inverted funnel placed above baffles near the top of the reactor. Biogas composition was determined using a gas chromatograph (GC-8A, Shimadzu, Kyoto) with a thermal conductivity detector equipped with a steel column packed with WG-100 (GL Sciences, Tokyo) at $50^{\circ} \mathrm{C}$. Volatile fatty acids (VFAs) were determined with a gas chromatography (W-NK-O.SA, Shinagawa) equipped with a $2 \mathrm{~m} \times 4 \mathrm{~mm}$ glass column packed with Suplocopor (100-120 mesh) coated with $10 \%$ Fluorad FC 431. The temperatures of the column, the injection port, and the flame ionization detector were 130,220 , and $240^{\circ} \mathrm{C}$, respectively. Effluent and biogas production rates were measured and analyzed weekly, whereas biomass concentration was analyzed biweekly for each loading rate.

\section{RESULTS AND DISCUSSION}

\section{COD removal in TP and CR}

Fig. 2 presents the average COD removal efficiencies in \%. The values were calculated based on the 12-month COD contents in the influent and effluent in TP and CR. The variations in COD concentration and removal in $\mathrm{CR}$ was greater than those in the TP (Fig. 2). In the latter case, variations in the concentration of COD in primary treatment lead were sharper than those in the secondary treatment. The maximum degradability rate of COD $59.9 \%$ was faster and COD removal was found to be $85.5 \%$ by CR, whereas that in the TP was only $70 \%$, which was varying and higher than those of primary treatment where COD removal is approximately $53 \%$ Table 3. These trends were observed throughout the study period of 12 months, indicating that these COD originated from the same respective sources. COD degradability depends on the $\mathrm{CH} 4$ emission rate in both TP and CR. An average of $0.109 \mathrm{~g}$ of $\mathrm{CH}_{4}$ was produced from a $1 \mathrm{~g}$ of COD (Fig. 2). During the operation an average COD of POME was $45000 \pm 2189 \mathrm{mg} / \mathrm{l}$ while the CR treated POME was $2435 \pm 1176 \mathrm{mg} / \mathrm{l}^{18}$.
The COD removal occurs in both primary treatment (where a portion of organics is adsorbed on to the particles) and secondary biological treatment (where COD is removed by anaerobic digestion of volatile fatty acids) ${ }^{8}$. Biological treatment systems are chiefly designed for the removal of organic carbon by activated sludge microorganisms. Therefore, removal of organics by these systems may be regarded as a side benefit, minimizing the amount of carbon emission and sludge disposal and producing biogas and methane $e^{9,20}$.

As shown in Fig. 2, the COD concentration in both tanks was almost the same until September, but open tank showed a comparatively low COD concentration in October and November 2011, perhaps because there was more rainfall during these months in which COD concentration was reduced because of rain water dilution in the open tank. On the other hand, the closed tank was obviously not affected by rainfall because of closed anaerobic environment. ${ }^{27}$ studied pollution control technologies for the treatment of POME and reported similar observations.

The variation in the contents of $\mathrm{CH}_{4}$ (Fig. 3) and $\mathrm{CO}_{2}$ (Fig. 4) in the effluent was more pronounced. The variation in the content of $\mathrm{CH}_{4}$ was the most pronounced, whereas that of VFA and $\mathrm{CO}_{2}$ varied in the first six months and later remained stable, with few exceptions. These observed stable contents of $\mathrm{CH}_{4}, \mathrm{CO}_{2}$, and biogas in the effluent corresponded well with their respective stable contents in the influent stream.

VFA conversion and biogas production are affected by the treatment system itself. For example, when removal efficiencies are calculated, only the COD/VFA contents in the influent stream are considered in comparison with that in the effluent. However, from the conceptual model shown (Fig. 1), the biological treatment system is potentially overloaded with VFA contained in the returned streams, namely, recycled activated sludge and returned wastewater. The treatment and degradation of VFA in the treatment systems seem to be influenced by the following mechanisms: (1) acetogenesis, conversion of butyrate to acetate and hydrogen; (2) methanogenesis, cleavage of acetate 
to $\mathrm{CH}_{4}$ and $\mathrm{CO}_{2}$; and (3) reduction of $\mathrm{CO}_{2}$ to $\mathrm{CH}_{4}$ $[28,29]$. The effects of VFA contents were in the return streams (Fig. 5) on the wastewater influent and effluent COD/VFA contents (consequently, on their removal efficiencies). In addition, it is not known which organic and inorganic components of the sludge are anaerobically degraded and how such degradation processes affect the contents of $\mathrm{CH}_{4}$ and $C O D$ in the sludge.

\section{Volatile fatty acid concentration}

Fig. 5 shows the VFA concentrations in TP and CR during a one-year period. From August to July, the VFA concentration in both tanks was increased slightly, although the CR had higher VFA concentration because of anoxic treatment conditions. However VFA reduction from 790 to 230 $\mathrm{mgl}^{-1}$; this reduction could not increase the biogas production because dilution of normal water during biodegradation of organic matter lowers the reaction rate during the treatment process.

The VFA concentrations in the CR were relatively high (400-1240 $\left.\mathrm{mgl}^{-1}\right)$ because the treatment process is totally anaerobic. The high concentration of VFA in the closed tank is due to the faster reaction rate in the absence of oxygen.

Table 1: Physio-chemical characteristics (POME)

\begin{tabular}{lc}
\hline Parameter $^{*}$ & Raw POME \\
\hline pH & 4.5 \\
Biological oxygen demand (BOD) & 31.5 \\
Chemical oxygen demand (COD) & 65.0 \\
Alkalinity & 2993 \\
Total solid (TS) & 39.0 \\
Suspended solid (SS) & 18.9 \\
Total phosphorus (TP) & 950 \\
Total organic carbon (TOC) & 25000 \\
Total nitrogen (TN) & 945 \\
Total kjeldal nitrogen (TKN) & 0.77 \\
Volatile fatty acid (VFA) & 1900 \\
Oil \&Grease & 3.97 \\
SO & 5 \\
\end{tabular}

${ }^{*}$ All parameters are in $\mathrm{g} \mathrm{L}^{-1}$ except $\mathrm{pH}$

a as TSS

${ }^{\mathrm{b}}$ as total nitrogen
Moreover, the conversion of acidogenesis into acetogenesis requires less time compared with that during partial anaerobic conditions

When the VFA concentrations in the two tanks were compared, the organic decomposition under full anaerobic conditions was observed to be stronger than that under partial anaerobic condition (Fig. 5). Furthermore, by comparing the biogas production at the same time, the closed anaerobic tank produced more gas than the open tank, although VFA concentration in the closed tank was relatively higher than that in the open tank. Fatty acid accumulation inhibits biogas production as reported in earlier studies; however, up to a certain level of VFA accumulation (2,000-3,000 mgl-1), biogas production is not disturbed [30]. Because of this, the biogas production rate in both tanks was almost low, but it was continued because of the low concentration of VFA in the organic matter ${ }^{31}$ found low biogas yield and organic matter removal because of the accumulation of inhibiting substances, such as volatile fatty acids $^{32}$ reported that COD removal was greater than VFA removal at the same $\mathrm{pH}$ and initial concentrations ${ }^{20}$. Furthermore, VFA removal efficiency is affected not only by VFA species and concentration but also by other conditions, such as operating parameters and physical, chemical, and biological factors ${ }^{33}$. For example, it is known that VFA removal by activated sludge is dependent on dissolved organic matter ${ }^{34}$ and $\mathrm{pH}^{35,36}$, whereby

Table 2: Composition and characteristics of the pre-treated POME

\begin{tabular}{lc}
\hline Parameters & Concentration \\
\hline $\mathrm{pH}$ & 4.2 \\
$\mathrm{COD}$ & $43.4 \mathrm{~g} / \mathrm{l}$ \\
$\mathrm{BOD}_{5}$ & $9.8 \mathrm{~g} / \mathrm{l}$ \\
$\mathrm{TSS}$ & $15.3 \mathrm{~g} / \mathrm{l}$ \\
$\mathrm{VSS}$ & $10.5 \mathrm{~g} / \mathrm{l}$ \\
$\mathrm{TVFA}$ & $2.54 \mathrm{~g} / \mathrm{l}$ \\
$\mathrm{TKN}$ & $536 \mathrm{mg} / \mathrm{l}$ \\
$\mathrm{P}$ & $98 \mathrm{mg} / \mathrm{l}$ \\
$\mathrm{Fe}$ & $290 \mathrm{mg} / \mathrm{l}$ \\
$\mathrm{Ca}$ & $310 \mathrm{mg} / \mathrm{l}$ \\
$\mathrm{Mg}$ & $235 \mathrm{mg} / \mathrm{l}$ \\
$\mathrm{Na}$ & $7 \mathrm{mg} / \mathrm{l}$ \\
$\mathrm{K}$ & $720 \mathrm{mg} / \mathrm{l}$ \\
\hline
\end{tabular}


the removal efficiency increases with increasing $\mathrm{pH}$ until fatty acids precipitate as hydroxides. Moreover, biological wastewater treatment is normally conducted at $\mathrm{pH} 7-9$. A major limitation of the anaerobic digestion of fruit and vegetable wastes in single-stage system is the rapid production of volatile fatty acids attributed to $\mathrm{pH}$ decrease during acidification that stressed and inhibited the activity of methanogenic bacteria [29]. The relationship between influent COD contents and their removal efficiencies (Fig. 2) is consistent with the findings of other researchers ${ }^{22,37}$, who observed that COD and VFA removal efficiencies were directly proportional to influent concentrations.

\section{Comparison of TP and CR treatment}

The waste sludge from primary and secondary treatment processes is stabilized by anaerobic digestion, which involves microbial decomposition of organic and inorganic matter. In the treatment plant investigated, the mixed sludge was introduced in the TP at intervals, retained in the digester for 38 days, and then intermittently disposed of as digested sludge. COD in the sludge is present as organic compound, precipitates in the sludge flocks, complexes of soluble organics and biopolymers, and degraded soluble organics in the microbial cells [38]Brown and Lester, 1979. M.J.

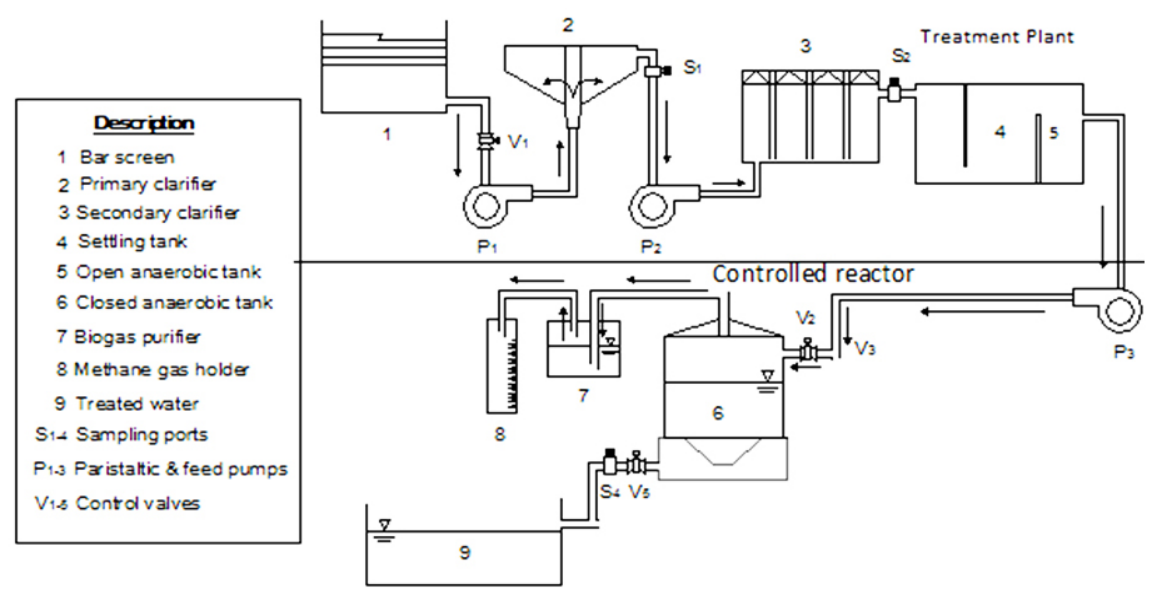

Fig. 1. Experimental setup of biological treatment systems of palm oil mill effluent (POME)

Table 3: Results obtained during primary treatment of POME

\begin{tabular}{lllllllc}
\hline $\begin{array}{l}\text { Time } \\
(\mathbf{m})\end{array}$ & $\begin{array}{l}\text { VFA } \\
(\mathbf{g} / \mathbf{l})\end{array}$ & $\begin{array}{c}\text { TOC } \\
(\mathbf{g} / \mathbf{l})\end{array}$ & $\begin{array}{c}\text { Biogas } \\
\mathbf{( I )}\end{array}$ & $\begin{array}{c}\text { TSS } \\
\mathbf{( g / l )}\end{array}$ & $\begin{array}{c}\text { VSS } \\
\mathbf{( g / l )}\end{array}$ & $\begin{array}{c}\text { COD } \\
(\mathbf{m g} / \mathbf{l})\end{array}$ & $\begin{array}{c}\text { COD } \\
\text { degradability } \\
\text { rate \% }\end{array}$ \\
\hline Aug 10 & 4.2 & 0.04 & 0.092 & 5.2 & 4.0 & 19704 & 54.6 \\
Sep 10 & 2.2 & 0.05 & 0.049 & 5.9 & 4.1 & 21787 & 49.8 \\
Oct. 10 & 3.0 & 0.03 & 0.059 & 5.6 & 3.9 & 19053 & 56.1 \\
Nov. 10 & 2.5 & 0.04 & 0.071 & 5.5 & 3.8 & 24493 & 58.9 \\
Dec. 10 & 2.6 & 0.02 & 0.035 & 6.7 & 5.2 & 24955 & 42.5 \\
Jan. 11 & 3.6 & 0.02 & 0.025 & 5.9 & 4.3 & 21222 & 51.1 \\
Feb. 11 & 4.5 & 0.04 & 0.047 & 5.6 & 4.0 & 17403 & 59.9 \\
Mar. 11 & 3.1 & 0.05 & 0.036 & 6.0 & 5.0 & 18488 & 57.4 \\
Apr. 11 & 4.8 & 0.05 & 0.031 & 5.8 & 4.4 & 20181 & 53.5 \\
May 11 & 3.0 & 0.06 & 0.037 & 6.1 & 4.5 & 19182 & 55.8 \\
June 11 & 3.5 & 0.05 & 0.063 & 6.2 & 4.1 & 19703 & 54.6 \\
Jul 11 & 4.4 & 0.06 & 0.078 & 6.5 & 4.2 & 21396 & 50.7 \\
\hline
\end{tabular}


Brown and J.N. Lester, Metal removal in activated sludge: the role of bacterial extracellular polymers. Water Research 13 (1979), pp. 817-837. Abstract I PDF (2013 K) I View Record in Scopus I Cited By in Scopus (120). Fig. 2 and 5 show the results of COD and VFA of organic contents in both undigested and digested sludge. Both streams were characterized by highly fluctuating COD, VFA, and organic contents. Moreover, TP and CR digestion caused a decrease in TSS content in Fig. 6 that mean COD and VFA reduction on dry weight basis. The reduction in TSS contents in the effluent from 3615 to $1026 \mathrm{mgl}^{-1}$ by TP and from 3617 to $438 \mathrm{mgl}^{-1}$ by CR. After treatment of POME by CR the reduction of TSS approximately $65 \%$ means this technique reduce the burden of sludge in our environment. (Fig. 6) and organic matters are degraded into end products including $\mathrm{CH}_{4}, \mathrm{CO}_{2}, \mathrm{~N}_{2}, \mathrm{H}_{2} \mathrm{~S}$, and some trace gases ${ }^{39}$.
Because the determination of $\mathrm{CH}_{4}$ contents was based on COD reduction, the reduction of such organic and inorganic matters probably caused the observed increase in $\mathrm{CH}_{4}$ contents in the $\mathrm{CR}$ is more than TP, where as the degradation of COD in TP $58 \%$ and $85 \%$ in CR. ${ }^{40}$ indicated that the digestibility of organic components in the POME was in the following order: VFA $<\mathrm{CH}_{4}<\mathrm{CO}_{2}<\mathrm{H}_{2}$. Furthermore, the volatilization/solubilization of organics to the atmosphere from activated sludge systems also is known ${ }^{41}$. Such organic losses, although probably not a major factor, could have contributed to the inconsistency and variation in $\mathrm{CH}_{4}$ and $\mathrm{CO}_{2}$ content increases in the digested sludge. ${ }^{8}$ investigated the treatment of POME using aerobic oxidation based on an activated sludge process. A possible reason for the increased removal of organic matter as well as oil and grease in the anaerobically digested sample was the presence of partially degraded organic and oil

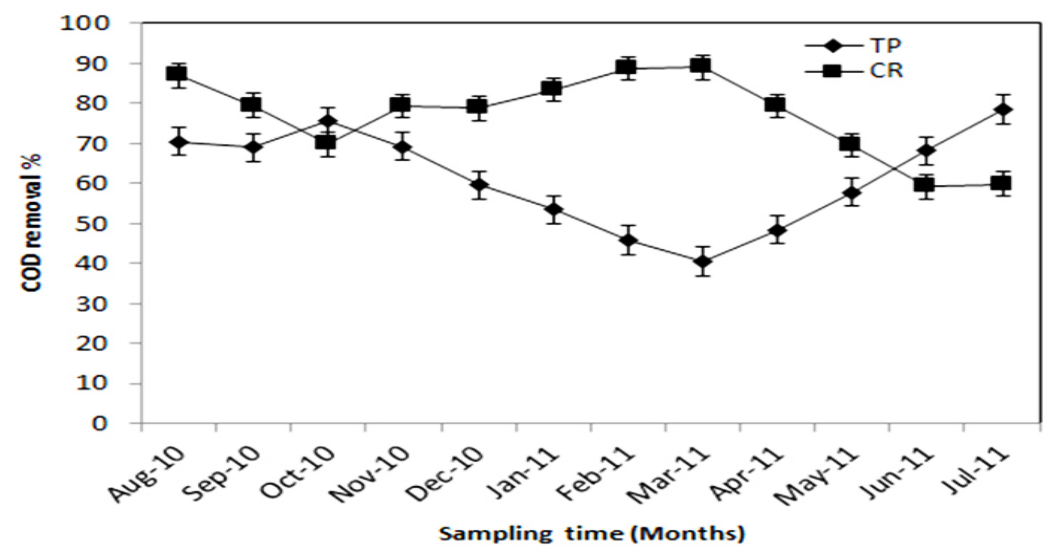

Fig. 2: COD removal \% in TP and CR.

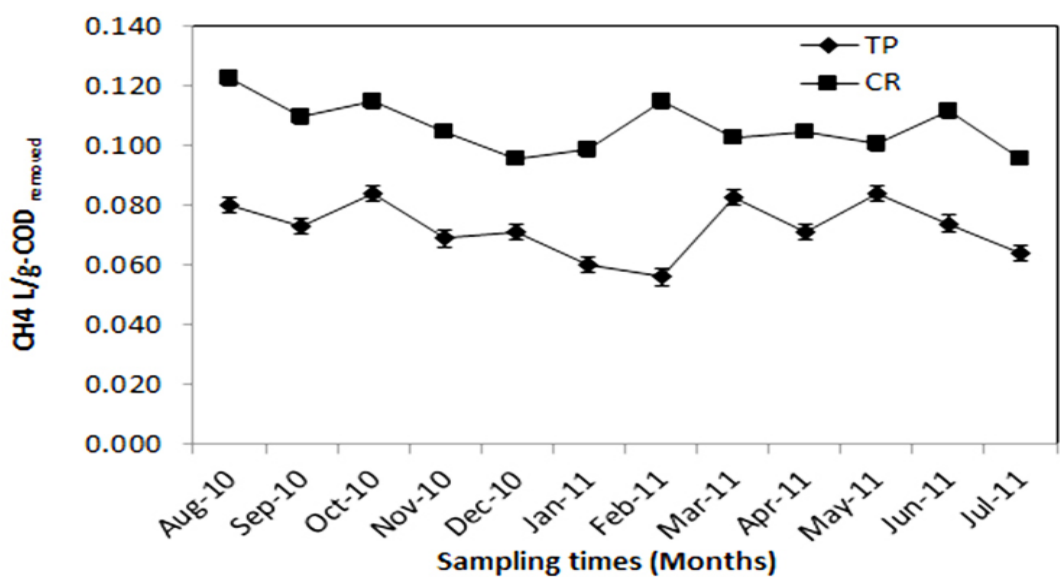

Fig. 3: $\mathrm{CH}_{4}$ gas content in TP and CR conditions. 


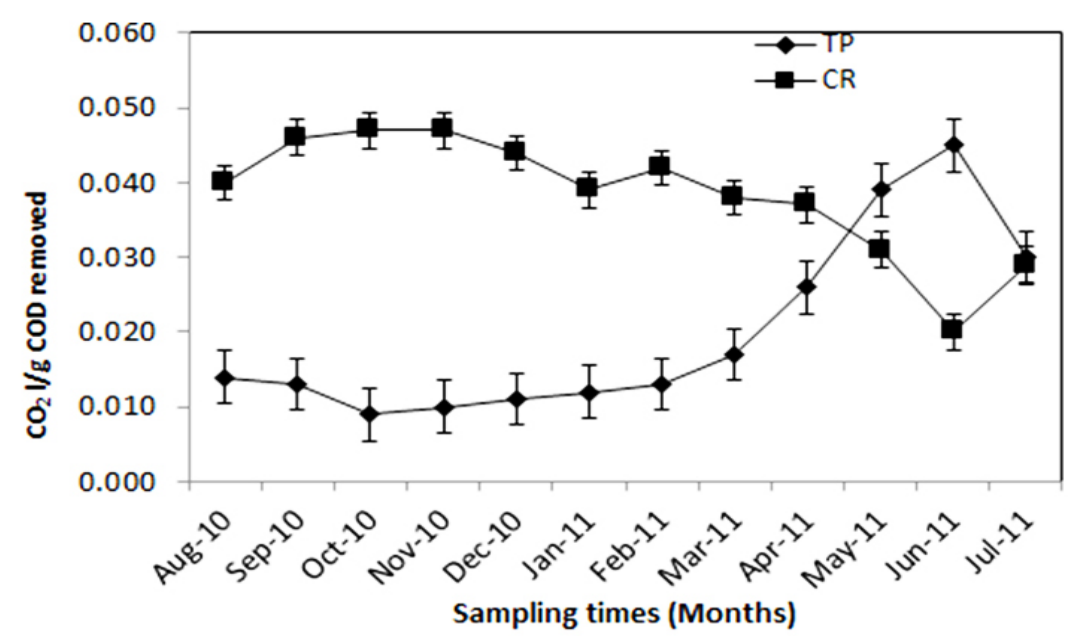

Fig. 4: $\mathrm{CO}_{2}$ gas reduction mean capture in TP and CR conditions.

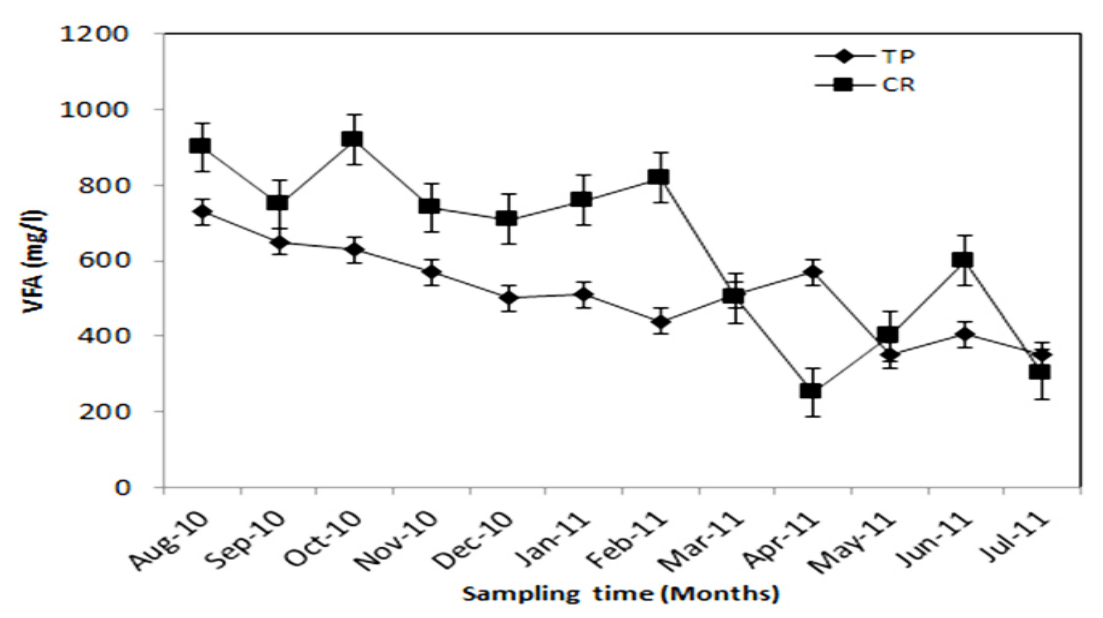

Fig. 5: A-VFA concentration B- VFA reduction in TP and CR conditions.

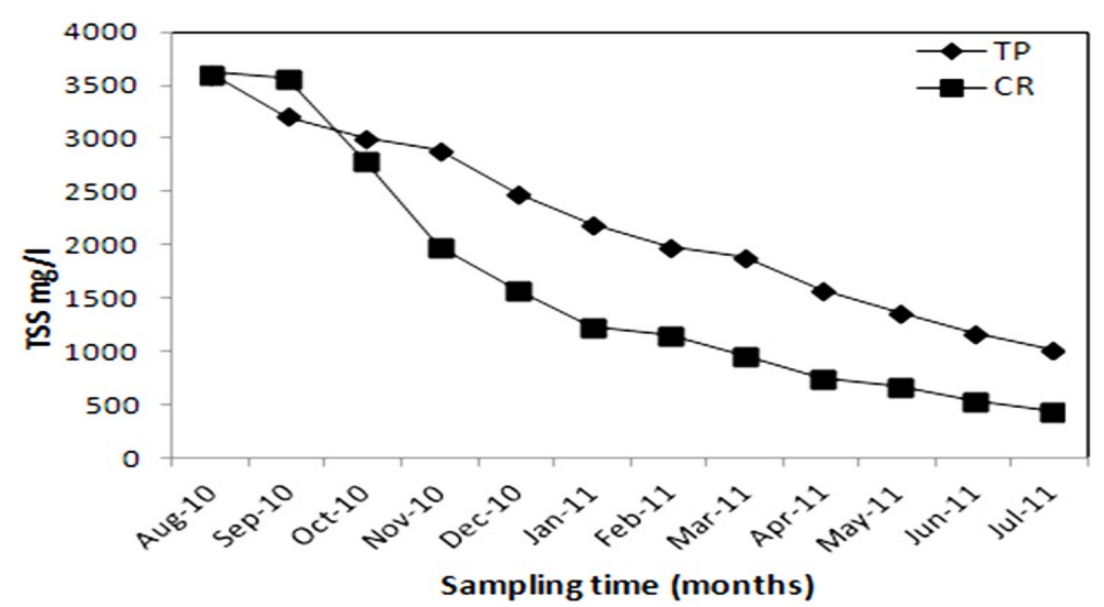

Fig.6: TSS concentration in TP and CR conditions. 
molecules, making them more amenable to aerobic digestion.

Fig. 3 show the average $\mathrm{CH}_{4}$ contents in undigested sludge. The increase in the content of VSS, which was the highest in the undigested sludge, was seemingly the lowest. Also, the content of $\mathrm{CH}_{4}$, which was the lowest in the undigested sludge, increased more (approximately 97\%) than that of the other parameters. As per survey a total amount of POME was discharge $235640 \mathrm{t}$ in 2005 and COD was $45000 \pm 2189 \mathrm{mgl}^{-1}$. After the treatment of POME by TP sludge was $506 \pm 254$ and CR $354 \pm 127 \mathrm{gl}^{-1}$ in $\mathrm{I}^{-1}$ of POME. This is best techniques to evaluate the treatment of by TP and CTE to $\mathrm{CH}_{4}$ production $\mathrm{g}^{-1}$ of COD and sludge management. In principle, the results of this study indicate that LHSC meets the compliance limits (COD, VFA, $\mathrm{CH}_{4}$ and TSS) for treated wastewater in accordance with the decree issued by the Malaysian Ministry of Environmental Protection about the characteristics of wastewater for disposal to water or land.

\section{CONCLUSIONS}

For the wastewater treatment system investigated, when the contents of COD and VFA are equal to 19.9 and $1240 \mathrm{mgl}^{-1}$, respectively, their reduction is insignificant. Thus, the COD removal is directly proportional to the influent concentrations. The reduction of COD contents was in the following increasing order: $\mathrm{CH}_{4}<\mathrm{VFA}<\mathrm{CO}_{2}$, which directly corresponded to their COD initial influent wastewater contents. A relation was also established between TP and CR for VFA reduction rates where $110 \mathrm{mg} / \mathrm{l}$ in CR, where as in TP $570 \mathrm{ml}^{-1}$ in November month was observed. The investigated CR system meets the compliance limits for treated wastewater. While for every $g$ of $C O D$ of POME discharged, an average of $0.106 \mathrm{I}$ of $\mathrm{CH}_{4}$ will be produced from the $\mathrm{CR}$ compared to TP $0.072 \mathrm{I} \mathrm{of} \mathrm{CH}_{4}$. The results presented herein indicate that a long term observation is crucial to determine the $\mathrm{CH}_{4}$ POME $\left(\mathrm{t}^{-1} \mathrm{~d}\right) \mathrm{CH}_{4}\left(\mathrm{t}^{-1}\right.$ d). Relationship between $\mathrm{CH}_{4}$ from VFA reduction $86 \%$ showing high rate degradability rate of $P O M E$ through our system. However, after treatment of POME by CR the reduction of TSS approximately $65 \%$ means this technique reduces the burden of sludge in our environment.

\section{ACKNOWLEDGEMENTS}

The authors thank the deanship of scientific research (DSR) at King Saud University (KSU) for its funding of this research through the research group project no. RGP-VPP-316.

\section{REFERENCES}

1. G.D. Najafpour, A.A.L. Zinatizadeh, A.R. Mohamed, M.H. ISA, H.Nasrollahzadeh, High rate anaerobic digestion of palm oil mill effluent in an upflow anaerobic sludge-fixed film bioreactor, Process Biochemistry 41, 370-379, (2006).

2. P.E. Poh, M.F. Chong, Development of anaerobic digestion methods for palm oil mill effluent (POME) treatment, Bioresour. Technol. 100(1), 1-9 (2009).

3. M.A. Latif, R. Ghufran, Z.A. Wahid, A. Ahmad, Integrated application of upflow anaerobic sludge blanket reactor for the treatment of wastewaters, Water Research 45, 4683-4699, (2011).
4. Intergovernmental Panel on Climate Change (IPCC). The physical science basis. contribution of working group-1 to the fourth assessment report of the IPCC, New York, Cambridge. http://ipcc-wg1. ucar.edu/wg1/ wg1-report.html, 2007.

5. I.E. Henson, Modelling carbon sequestration and greenhouse gas emissions associated with oil palm cultivation and land-use change in Malaysia-a re-evaluation and a computer model. MPOB Technology, -No 31, May 2009.

6. Evaluation of the Bio-Kinetics of Cement Kiln Dust in an Upflow Anaerobic Sludge Blanket Reactor for Treatment of Palm Oil Mill Effluent 
as a Function of Hydraulic Retention time. Separation and Purification Technology 133, 129-137 (2014)

7. S.L. Tong, A.B. Jaafar, POME Biogas capture, upgrading and utilization, Palm Oil Engineering Bulletin. 78: 11-17, (2006).

8. K. Vijayaraghavan, D. Ahmad, M.E. Abdul Aziz, Aerobic treatment of palm oil mill effluent, J. of Environ. Management. 82, 24-31, (2007).

9. A. Ahmad, R. Ghufran, Z.A. Wahid, Method for use in Palm oil mill effluent (POME) treatment U.S. Patent No.20120040442- A1-(2012).

10. A. Ahmad, R. Ghufran, Z.A. Wahid, Effect of COD loading rate on an upflow anaerobic sludge blanket reactor during anaerobic digestion of palm oil mill effluent with butyrate, J. of Environ, Engi. Lands. Manage, 20, 256-264, (2012).

11. A. Ahmad, A novel application of red mud-iron on granulation and treatment of palm oil mill effluent using upflow sludge blanket reactor. Environmental Technology DOI:10.1080/095 93330.2014.919034. (2014).

12. W. Parawira, J.S. Read, B. Mattiasson, L. Björnsson, Energy production from agricultural residues: high methane yields in pilot scale two-stage anaerobic digestion, Biomass Bioenergy, 32: 44-50, (2008).

13. J.B. Davis, Palm oil mill effluent: a review of methods proposed for its treatment, Tropical Science, 20: 233-262, (1978).

14. J. O. Edewor, A comparison of treatment methods for palm oil mill effluent (POME) wastes, Journal of Chemical Technology Biotechnology, 36: 212-218, (1986).

15. P. Agamuthu, Palm oil mill effluent e treatment and utilization. In: Sastry CA, Hashim MA, Agamuthu P, (Eds.). Waste Treatment Plant, New Delhi: Narosa Publishing House, 1995.

16. M. Tabatabaei, M.R. Zakaria, R.A. Rahim, A.D.G. Wright, Y. Shirai, N. Abdullah, K. Sakai, S. Ikeno, M. Mori, M. Kazunori, A. Sulaiman, M.A. Hassan, PCR-based DGGE and FISH analysis of methanogens in an anaerobic closed digester tank for treating palm oil mill effluent, EleCRonic J. of Biotechnology, 12(3): 717-3458, (2009).

17. A.L. Ahmad, M.F. Chong, S. Bhatia, Mathematical modelling of multiple solutes system for reverse osmosis process in palm oil mill effluent (POME) treatment, Chemical Engineering Journal, 132: 183-193, (2007).

18. A. Ahmad, R. Ghufran, Z.A. Wahid, Role of calcium oxide in sludge granulation and methanogenesis for the treatment of palm oil mill effluent using UASB reactor, J. of Hazardous Material, 198: 40-48, (2011a).

19. M.A.I. Karim, L.L. Hie, The use of coagulating and polymeric ûocculating agents in the treatment of palm oil mill efûuent (POME), Biological Wastes, 2: 209-218, (1987).

20. A. Ahmad, R. Ghufran, Z.A. Wahid, Bioenergy from anaerobic degradation of lipid, Revie. Environ. Sci. and Biotechnol. DOI: 10.1007/ s11157-011-9253-8, 2011b.

21. M. VLAD, À. Chiriac, S. Constantinescu, S. Balta. Removal of the Pollutants from Wastewater through Coagulation-flocculation Process. Journal of Environmental Protection and Ecology V12, No 3A, 1517-1524, (2011).

22. S. Yacob, Y. Shirai, M.A. Hassan, M. Wakisaka, S. Subash, Start-up operation of semicommercial closed anaerobic digester for palm oil mill effluent treatment, Process Biochemistry, 41: 962-964, (2006).

23. A. Damayanti, Z. Ujang, M.R. Salim, G. Olsson, A.Z. Sulaiman, Respirometric analysis of activated sludge models from palm oil mill efûuent. Bioresour. Technology, 101: 144-149, (2010).

24. B.J. Wood, A review of current methods for dealing with palm oil mill efûuent, The Planter. 53: 477-495, (1995).

25. A.D. Eaton, L.S. Clesceri, A.E. Greenberg, Standard Methods for the Examination of Water and Wastewater. Washington, DC: American Public Health Association, 1995.

26. American Public Health Association (APHA). Standard Methods for the examination of Water and Wastewater, 19th Ed. Washington, D.C.; (1995).

27. Y.T. Wu, M.A. Wahab, J.M. Jahim, N. Anuar, Pollution control technologies for the treatment of palm oil mill effluent (POME) through end-of-pipe processes, J. of Environ. Management, 91: 1467-1490, (2010).

28. M.A. Hassan, S. Yacob, Y. Shirai, Y.T. Hung, Treatment of Palm Oil Wastewaters. In: 
Handbook of Industrial and Hazardous Wastes Treatment. Wang, L.K., Y. Hung, H.H. Lo and C. Yapijakis (Eds.). New York: Marcel Dekker, ISBN: 0824741145, 2004.

29. G. Mosoarca, A. Negrea, Studies Regarding the Effects of Settling Tanks Sludge Recycling on Organic Matter Concentration from Treated Water. Journal of Environmental Protection and Ecology 13: 198-202 (2012).

30. B. Negreanu-Pirjol, T. Negreanu-Pirjol, N. Badea, G. M. Parachiv, E. Gorun, R. Sirbu, A. Meghea, Physicochemical and Microbiological Characterisation of Municipal Sludge from Romanian Black Sea Coast Wastewater Treatment Plants. Journal of Environmental Protection and Ecology 13: 2232-2239 (2012).

31. A. Ahmad, A.A. O-Aljasser, Anaerobic Nitrogen, Sulfide and Carbon Removal in Anaerobic Granular Bed Reactor. Environ. Progress DOI 10.1002/ep.11882 (2013).

32. A.W. Zularisam, A. Ahmad, M. Sakinah, A.F. Ismail, T. Matsuura, Role of natural organic matter (NOM), colloidal particles, and solution chemistry on ultrafiltration performance, Separat. and Purifica. Technol, 78: 189-200 (2011).

33. M.A. Latif, R. Ghufran, Z.A. Wahid, A. Ahmad, Effect of Temperature and Organic Loading Rate on Upflow Anaerobic Sludge Blanket Reactor (USBR) by Treating Liquidized Food Waste, Environ. Progress, 3: 114-121, (2011).

34. B. Zainuri, A. Sulaiman, M.A Hassan, Y. Shirai, S. Abd-Aziz, S. Yacob, M. Wakisaka, Improved anaerobic treatment of palm oil mill effluent in a semi-commercial closed digester tank with sludge recycling and appropriate feeding strategy. Pertanika J. Tropical Agriculture Science, 33(1): 27-37, (2010).

35. T. Setiadi, Husaini, A. Djajadiningrat, Palm oil mill effluent treatment by anaerobic baffled reactors: Recycle effects and bio-kinetics parameters, Water Science Technology. 34: 59-66, (1996).

36. M. Faisal, H. Unno, Kinetic analysis of palm oil mill wastewater treatment by a modified anaerobic baffled reactor, Biochemical Engineering Journal 9: 25-31 (2001).

37. R. Borja, C.J. Banks, B. Khalfaoui, A. Martin, Performance evaluation of an anaerobic hybrid digester treating palm oil mill effluent, J. of Environ. Scie. and Health., 31: 1379-1393 (1996a).

38. S.B. Thakre, L.B. Bhuyar, S.J. Deshmukh, Effect of different configurations of mechanical aerators on oxygen transfer and aeration efficiency with respect to power consumption, World Academy of Science Engine and Technology, 38: (2008).

39. E. U. Cokgor, G. Insel, E. Aydin, D. Orhon, Respirometric evaluation of a mixture of organic chemicals biodegradation kinetics, J. of Hazard. Material 161: 35-41 (2009).

40. A. Ahmad, Calcium oxide cement kiln dust for granulation of palm oil mill effluent, U.S. Patent No. 20120285884A1, (2012).

41. L. Singh, Z.A. Wahid, M.A. Siddiqui, A. Ahmad, M. Hasbi Ab-Rahim M. Sakinah, Application of immobilized upflow anaerobic sludge blanket reactor using Clostridium LS2 for enhanced biohydrogen production and treatment efficiency of palm oil mill effluent, 38(5): 2221-2229 (2013) 